IdeAs

Idées d'Amériques

$10 \mid 2017$

États-Unis / Cuba : une nouvelle donne?

\title{
Engage or Isolate? Twenty years of Cuban Americans' Changing Attitudes towards Cuba- Evidence from the FIU Cuba Poll
}

¿Acercamiento o aislamiento? Veinte años de cambios en las actitudes de los cubanoamericanos hacia relaciones entre Cuba/EE.UU. - Evidencia del FIU Cuba Poll

Rapprochement ou isolement? Vingt ans de changements dans l'attitude des Cubains-Américains à l'égard de Cuba à la lumière des sondages FIU Cuba

Guillermo J. Grenier

\section{CpenEdition}

Journals

Electronic version

URL: https://journals.openedition.org/ideas/2244

DOI: 10.4000/ideas.2244

ISSN: 1950-5701

Publisher

Institut des Amériques

Electronic reference

Guillermo J. Grenier, "Engage or Isolate? Twenty years of Cuban Americans' Changing Attitudes towards Cuba-Evidence from the FIU Cuba Poll", IdeAs [Online], 10 | 2017, Online since 19 December 2017, connection on 19 October 2022. URL: http://journals.openedition.org/ideas/2244 ; DOI: https:// doi.org/10.4000/ideas.2244

This text was automatically generated on 19 October 2022

Creative Commons - Attribution-NonCommercial-NoDerivatives 4.0 International - CC BY-NC-ND 4.0 https://creativecommons.org/licenses/by-nc-nd/4.0/ 


\title{
Engage or Isolate? Twenty years of Cuban Americans' Changing Attitudes towards Cuba-Evidence from the FIU Cuba Poll
}

\author{
¿Acercamiento o aislamiento? Veinte años de cambios en las actitudes de los \\ cubanoamericanos hacia relaciones entre Cuba/EE.UU. - Evidencia del FIU Cuba \\ Poll \\ Rapprochement ou isolement? Vingt ans de changements dans l'attitude des \\ Cubains- Américains à l'égard de Cuba à la lumière des sondages FIU Cuba
}

\section{Guillermo J. Grenier}

\section{Introduction}

1 While the flow of Cubans to the United States dates back to the $19^{\text {th }}$ Century (Poyo G., 1989), it is widely recognized that the contemporary Cuban presence in the United States is linked to the conditions created by the Revolution of 1959 and the geopolitics of the Cold War. Whereas previous migrations established communities in New York, Tampa and Key West, the post-1959 Revolution migration created in Miami-Dade County the largest Cuban diaspora population in the country. Almost half of the 2 million Cuban Americans in the United States live in Miami-Dade County. Most are post 1959 migrants (Lopez M.H. and J.M. Krogstad, 2014).

2 Because of its anti-Revolutionary origins, it is often assumed that the community's sociocultural and political characteristics are monolithic. That is, all Cubans in the United States are viewed as being made of the same anti/counter Revolutionary cloth, fiercely loyal to the Republican Party and supportive of U.S. policies which delegitimize and isolate the Cuban government. This monolithic view of the Cuban émigré is particularly directed at the Cubans living in the Miami-Dade metropolitan area. As 
Figures 1 and 2 make clear, Cubans are the dominant Latino group in Miami-Dade County. These Cuban Americans are frequently characterized by their monolithic ideological "right wing" leanings. This "Exile Ideology" shapes the national perception of the nature of the Cuban American community (Perez L., 1992; Grenier G. and L. Perez, 2003). To the degree that non-Cuban Americans think of Cubans in the Miami area, they are frequently characterized by their political features: staunch antiCastrism, militancy and political conservatism (Uhlander C. and F.C. Garcia, 2005).

Figure 1: Ethnic Make Up of Miami Dade County: 2010 Census

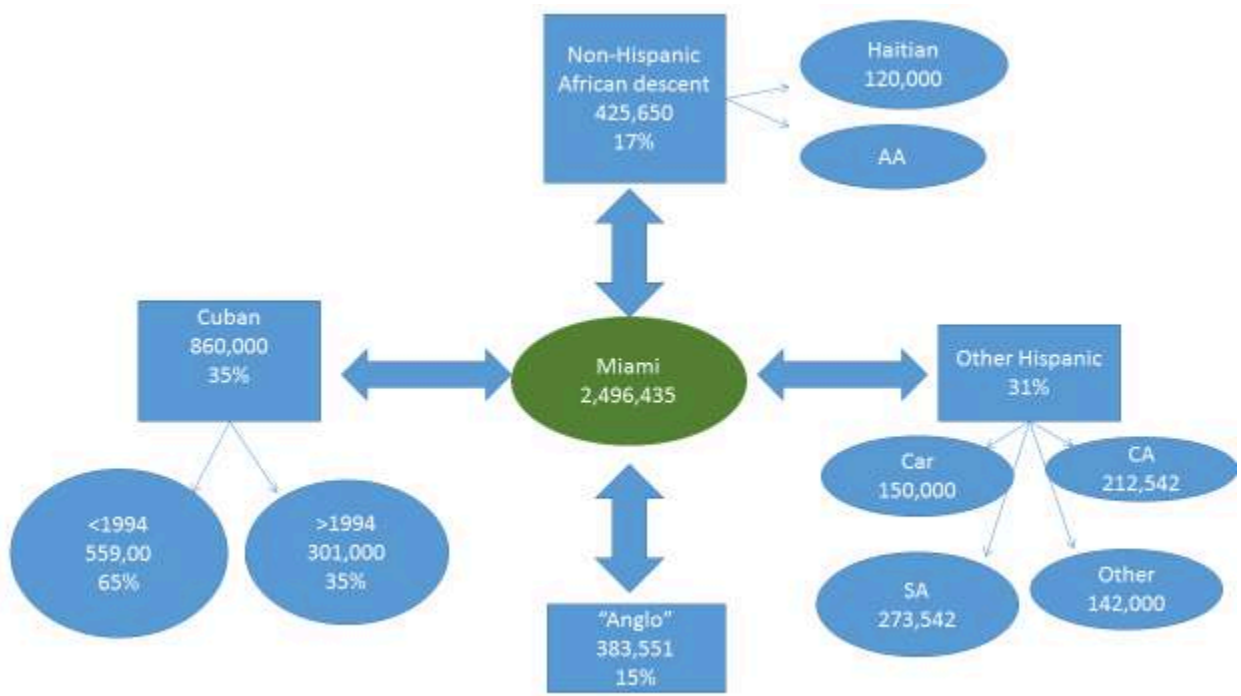

U.S. Census 2010

Figure 2: Latino Origin Population: Percent of Total Population (2\% or more)

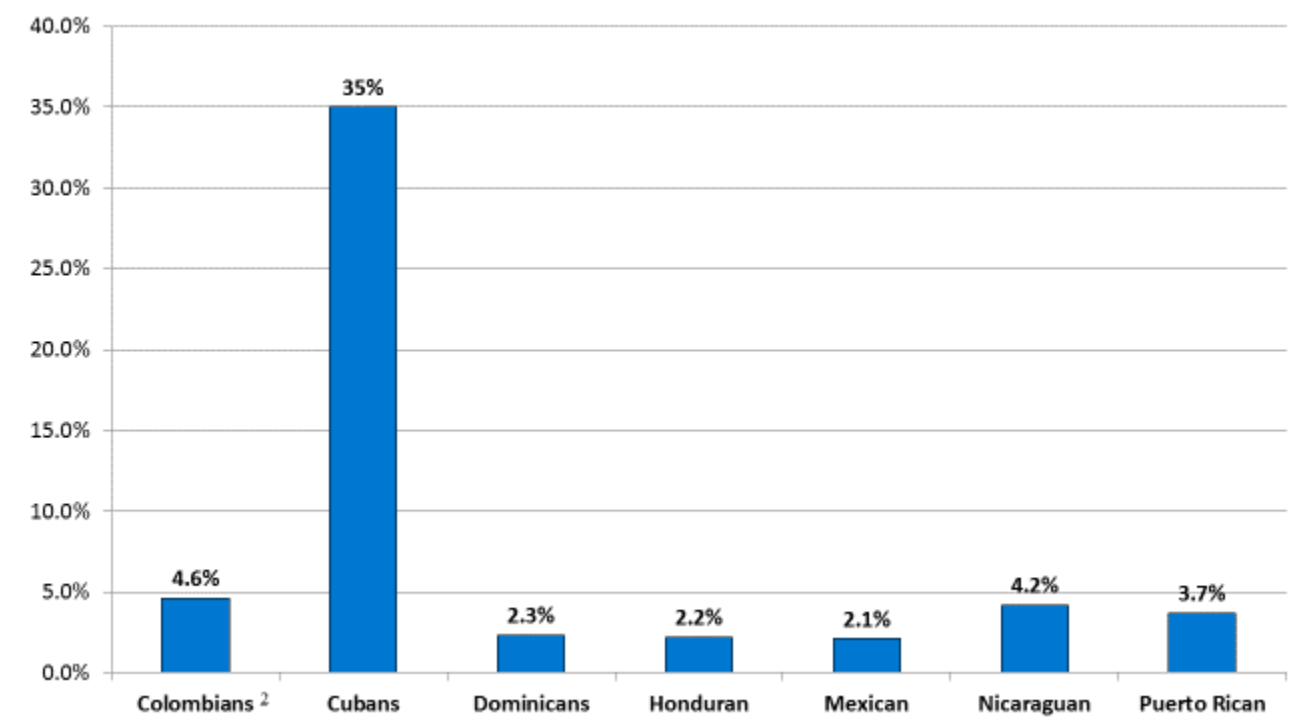

U.S. Census, 2010

3 Yet, in recent decades the Cuban community has grown increasingly diverse, ideologically and economically. Since the Mariel Boatlift in 1980 and, more recently, since the regularization of immigration brought about by the 1995 Immigration 
Agreement, which instituted the "wet foot/dry foot policy, and the changes in Cuban migration policy of January 2013, the Cuban population of Miami has developed socioeconomic and political characteristics unlike the earlier arrivals (Fernandez G., 2007; Newby C.A. and J. A. Dowling, 2007; Portes A. and A. Puhrmann, 2015). The diversification of ideological perspectives among Cubans is evident in the shrinking allegiance to the Republican Party. From the high of $70 \%$ percent in the 1990 s to an estimated minority of $46 \%$ of Cubans in Miami Dade are registered Republicans (Grenier G. and H. Gladwin, 2014). The diversification of the Cuban community can be observed across a wide range of attitudes and has contributed to the creation of a socio/political profile of the Cuban American community that is more aligned to the State and national Latino realities.

The existence of a diversity of political attitudes within the Cuban American community based on time of arrival in the United States has been well established in the literature (Grenier G., and L. Perez, 2003; Eckstein S. and L. Barberia, 2002, Eckstein S., 2009; Girard C. and G. Grenier, 2008; Girard C. et. al. 2010; Girard C. et al. 2012). The waves of departure from Cuba have been associated to the variation of attitudes to the embargo (Girard C. et. al, 2010), Republican Party registration (Girard C. and G. Grenier, 2012) and other measures of Cuban American political attitudes specifically related to U.S./Cuba policy (Grenier G. and H. Gladwin, 2014). Much of the empirical evidence for the argument supporting changing views comes from the FIU Cuba Poll, a poll which has tracked Cuban American attitudes about U.S. Cuba policy since 1991. Since its inception, the FIU Cuba Poll has measured the attitudes of Cuban Americans living in South Florida towards U.S./Cuba relations. The standardization of key questions as well as the frequency of the poll has allowed the understanding of the changing nature of Cubans in the United States, particularly its growing ideological diversity. This paper analyzes data from the 1997 to 2016 FIU Cuba Poll to explore the diversification of views within the Cuban American population in Miami-Dade County toward U.S./Cuba policies that encourage engagement with or promote isolation of the island.

5 In this article, I will present data from the combined data set of the Cuba Poll from 1997 to 2016. After reviewing the methodology, and establishing the theoretical framework, I will present the results of the key variables by poll year. This allows us to see change over time in the attitudes of the entire Cuban American population in Miami-Dade County. To view the changes by waves and generation, I will then present the data according to the time of respondent departure from Cuba and whether the respondent was born in Cuba or in the United States. A discussion of the trends will serve as a conclusion to the presentation.

\section{Methodology}

\section{Sample}

Data for the present analysis are taken from a data set combining eight Cuba Polls, from 1997 to 2016 (Figure 3). Each survey was conducted among Cuban Americans in Miami Dade County. The combined sample is comprised of 7731 valid respondents contacted via telephone using standard random digit dialing procedures. The data have been weighted to be representative of the appropriate demographic characteristics of the Cuban American population during each poll year. 
Figure 3: Cuba Polls 1997-2016 by Poll Year (Sample Size and Margin of Error +/-)

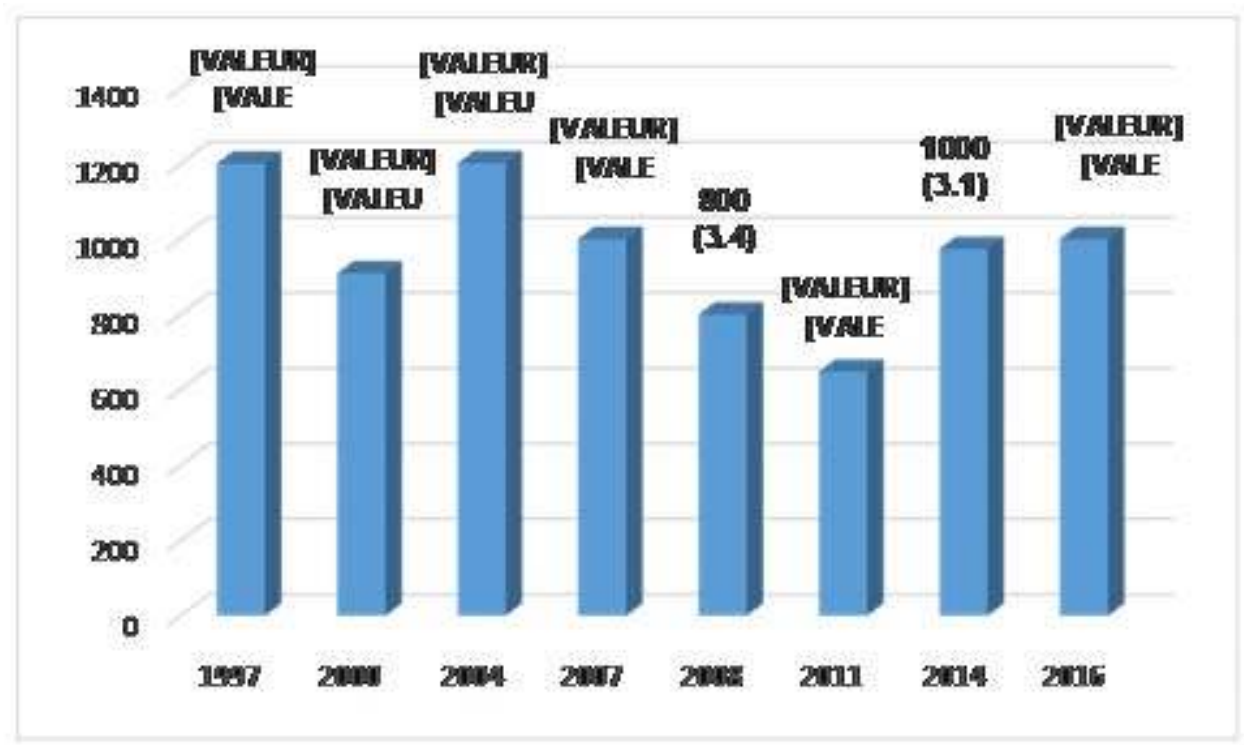

Source: FIU Cuba Poll: 1997-2016

\section{Variables}

7 Based on the theoretical frameworks which hypothesize distinctive world views based on distance from the foundation event (Sewell W., 2005), generation, (Mannheim K, 1952; Eckstein S., 2009) and wave (Grenier G., 2006), the present work analyses the results of the 1997-2016 Cuba Polls to explore the change over time of opinions on US/ Cuba policy among different generations and waves of Cuban American migrants living in the Metropolitan Miami Area.

\section{Dependent Variables}

We focus on the core attitudinal variables asked in all of our polls: 1) support for the embargo; 2) opposition to the establishment of diplomatic relations; 3) opposition to unrestricted travel by all Americans to Cuba; 4) having traveled to Cuba; 5) opposition to the selling of food to Cuba; and 6) opposition to selling medicines to Cuba.

\section{Independent variables}

9 Considerable research using independent FIU Cuba Polls has shown that more recent immigration waves, as well as Cuban Americans not born on the island, are the least supportive of some of the key components of the "exile ideology, although the individual components have not been tested to see if they measure a unitary concept (Grenier G., 2006; Girard C. and G. Grenier, 2008; Girard C. et. al. 2012). In this analysis we simplify the waves, based on previous research. We will look at four waves: 1959-1979, 1980-1994, 1995-2004 and 2005-2016. To test the impact of "generations" on isolationist attitudes toward the island, we compared the isolationist attitudes of Cubans born outside of Cuba with those born in Cuba. Birth outside Cuba served as a rough indicator of the second generation. 


\section{Change Over Time: Moving Away from Revolution and Exile}

Before presenting the changes in the attitudes of the Cuban American population in the last twenty years, it is important to conceptualize the importance of the event from which all attitudes stem: the Triumph of the Cuban Revolution in 1959. All analyses of the changing nature of Cuban American attitudes implicitly or explicitly give primacy to the Revolution in shaping the nature of the Cuban migration and Cuban perspectives of the homeland. Indeed, events in the homeland have served as the "push factor" for all of the major migration waves of Cubans into a diasporic existence. The framework borrowed from Pedraza-Bailey (1985) describes the varying characteristics of Cuban immigration as the result of the "changing phases of the Cuban revolution" (PedrazaBailey S., 1985: 4). The abrupt structural changes initiated by the Revolution during its early phases transformed the society and were eventually institutionalized into the bureaucratic operations of the nation-state. Both the processes of restructuring and those of bureaucratization had differential influences on the shaping of the migrant "vintages." The "waves" frame utilized by Grenier and collaborators implies changes in U.S. policy and events in Cuba which stimulate the opening and closing of the migratory "faucet" (Perez L., 1992). Early migrations are motivated by the Revolutionary restructuring of the Cuban socioeconomic environment and subsequent waves are motivated by events that facilitated departures or easier arrivals to the United States. Similarly, the three historical generations analyzed by Eckstein are associated with three significant events in revolutionary Cuba: the Revolution itself, the Mariel Boatlift, and the Special Period brought about by the dissolution of the Soviet Union.

11 The importance of events in the continued migration of Cubans to the United States can be framed by utilizing the lens of social historians. Social historians place great emphasis on the importance of the 'event' in shaping the lives and life chances of individuals experiencing it. Events are not just out of the ordinary happenings that draw our attention. The World Cup is an event, as is the birthing of a Royal baby, but they are not the types of occurrences that social historians consider to be of eventful social significance. Events, for historians, are social occurrences which "transform social relations" (Sewell W., 2005: 8). In Sewell's words, “...when historians argue for the importance of events, they have in mind occurrences that have momentous consequences, that in some sense "change the course of history" by transforming social structures and the institutions which stabilize social rituals and relationships (Sewell W., 2005: 200, 226). Such transformations unleash a chain of occurrences that durably transforms previous structures and practices. In their transformation of social structures (economy, politics, religion, etc.), events establish long term trends which, in turn, transform social relations over time and become the subject of social analysis. For social historians "[time] is fateful. Time is irreversible in the sense that an action, once taken, or an event once experienced cannot be obliterated. It is lodged in the memory of those whom it affects and therefore irrevocably alters the situation in which it occurs. (Sewell W., 2005: 7).

In our specific case, the Triumph of the Cuban Revolution in 1959 is the foundation event which initiated a sequence of subsequent events which shaped the motivations 
and options of migrants during specific periods since 1959. The first cause of the contemporary migration flow from Cuba to the United States was the Cuban Revolution of 1959. This event transformed the political structures of Cuba overnight and continued to restructure all of Cuban society for decades afterwards. The earliest of the migrants were motivated to leave their homeland not out of a desire to start new lives in a more promising sociocultural environment but out of fear that their lives would be negatively affected by the new order. Although few imagined that they would never return to their home, many of these earliest migrants considered themselves exiles and most suffered a loss of property and a diminished quality of life in their transition to the new land.

When we measure change over time, we are measuring change in attitudes in relation to this foundation event. We should expect that measurements of attitudes most proximate to the Triumph of the Revolution will express the harshest views against engaging the State apparatuses emerging from the Revolution. Similarly, as we posit when we look at the date by wave and generation, those who left the island as a direct result of the Revolution's triumph will hold the most hostile attitudes towards the ensuing government. While the Revolution was the first cause of all subsequent events, the sequence of significant events made possible by the Revolution had an impact on the migration flow between Cuba and the United States.

\section{Of Waves, Vintages and Generations}

Three frameworks have been utilized over the years to explain the emergence of a patterned ideological diversity within the community; the continuous flows of Cubans to the U.S. have been characterized as belonging to different "vintages," "waves," and "generations." In one of the earliest attempts to frame the Cuban migration in a context which recognizes its diversity, Pedraza-Bailey (1985) invokes the concept of "vintages" of migrants, formulated by Kunz (1973) to frame the causal forces shaping the differences evident in Cubans living in the U.S. at the time of her writing. The concept of "vintages" was formulated by Kunz as the foundation of a theory of refugee migration which recognized a distinction between refugee migrations that occur as immediate responses to structural changes and those that respond to changes that take a longer time to develop. As the sociopolitical situation changes during times of crisis in a country, groups of individuals will respond differently to the changes. "As the political situation ripens for each, they leave the country as distinct 'vintages' each usually convinced of the moral and political rightness of his actions and implicitly or openly blaming those who departed earlier or stayed on." (Kunz E. F., 1973: 137). These "vintages" of immigrants are distinct in "character, background, and avowed political faith (Kunz E.F., 1973: 137; Pedraza-Bailey, 1985: 4).

Grenier and collaborators, using the data from the FIU Cuba Poll, have explored the primacy of waves of departure in establishing the attitudinal patterns of Cuban émigrés to the United States. The "waves" are determined by significant changes in the migration flows between the two countries. Most analyses utilize the waves established by Grenier (2006) of eight cohorts: 1919-1958, 1959-1964, 1965-1973, 1974-1979, 1980, 1981-1989, 1990-1995, and 1996-2004 (Girard C. and G. Grenier, 2008). The earlier departures consistently express more support for the U.S. policies which isolate and attempt to destabilize the Cuban government while the most recent arrivals 
consistently hold more conciliatory views (Grenier G., 2006). This pattern has been maintained since the poll's inception in 1991 although the variance between the earliest and most recent arrivals has increased over the years (Grenier G. and $\mathrm{H}$. Gladwin, 2014).

Eckstein (2009) utilizes an adapted version of Mannheim's conceptualization of "generations" to identify three significant migration periods which shaped the characteristics of the Cuban immigrants: the period covering the Revolution and its aftermath produced the Exile émigré; the exodus authorized from the port of Mariel in 1980 produced the Marielitos; and the economic crisis resulting from the dissolution of the Soviet Union on December 25, 1991 gave rise to the migration of the "New" Cubans. These three migrations cohorts represent three different "meaningful generational experiences" that differentiate the immigrants from each other in the new country (Eckstein S., 2009: 39). Using the frequency data from various FIU Cuba Polls, Eckstein notes the different attitudes towards US/Cuba policy among the different waves of Cuban migrants and second generation (born in US) Cuban Americans. The New Cubans and the Second Generation are more likely to hold views encouraging engagement between the nation states as well as between individual Cubans. The political motivations of the early migrants, self-described as Exiles, are not shared by later waves of migrants. The economic factors influencing and often determining the migration decisions of the Cubans leaving the island after the fragmentation of the Soviet Union did not serve as motivators for the early arrivals. "With different pasts, the different émigré waves arrived with different perspectives on life in general and towards their homeland in particular." (Eckstein S., 2009: 3).

\section{Data Presentation and Results}

\section{Change Over Time}

17 Figures 4 through 7 show the variables by poll date. The trends are clear. There is a general shift in the Cuban American population towards a more conciliatory approach to dealing with Cuba. The position of isolation is slowly turning into a great support for engagement with the island's socioeconomic and political structures.

From the slight majority of fifty-six percent in 1997, support for the sale of medicines to Cuba increased to eighty-six percent by 2016. Similarly, the increase of support for the sale of food products doubled (40.8\%/80.8\%) in twenty years (Figure 4 ). 
Figure 4: Support for Sale of Food and Medicine

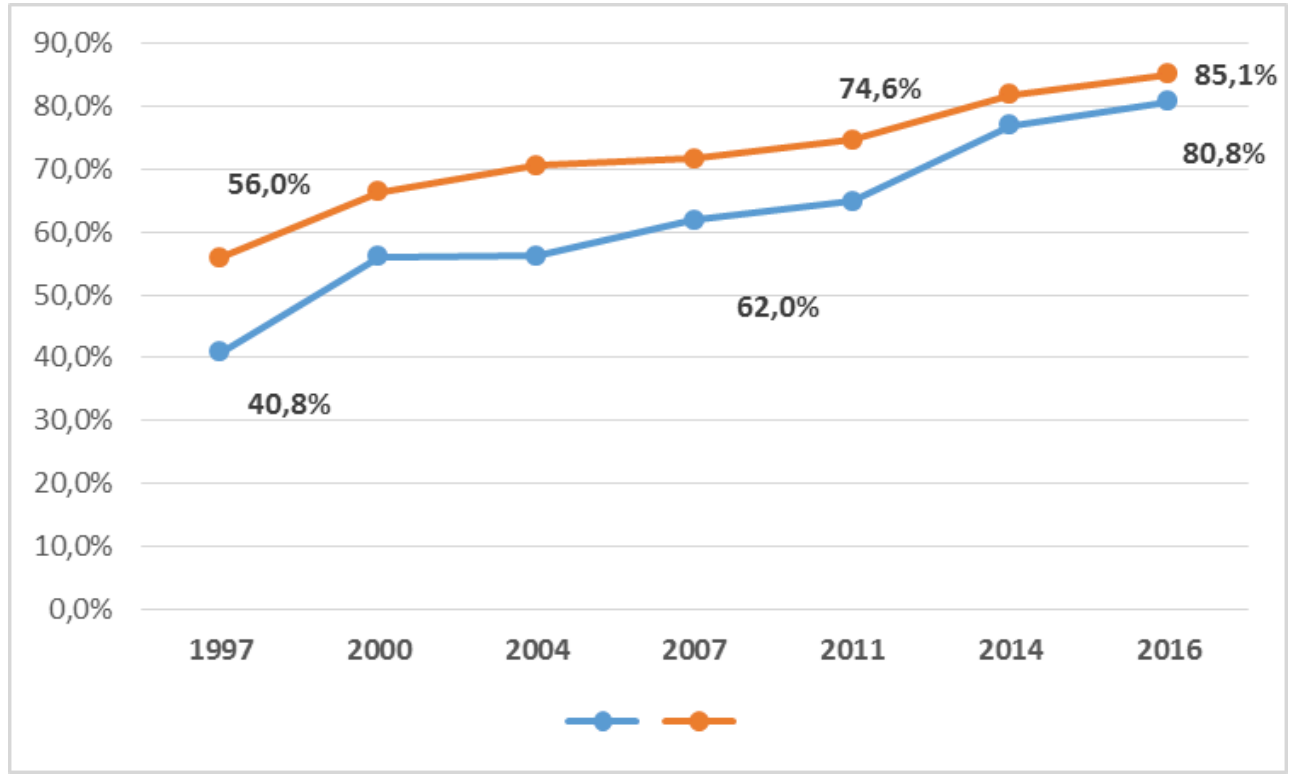

FIU Cuba Poll: 1997-2016

19 An increase in the desire for engagement can be seen in the trends associated with two other variables: the desire to make travel to Cuba available to all Americans and having traveled to Cuba. In 1997, only thirty percent of Cuban Americans in Miami-Dade County supported a policy of unrestricted travel to Cuba for all Americans. By 2016, over seventy-three percent expressed support for this policy change. The frequency of travel by Cuban Americans also increased during the two decades. Only twenty-three percent of Cuban Americans had traveled to Cuba by 1997. This rose to forty-five percent by 2016. (Figure 5)

Figure 5: Support for Unrestricted Travel and Have Traveled to Cuba

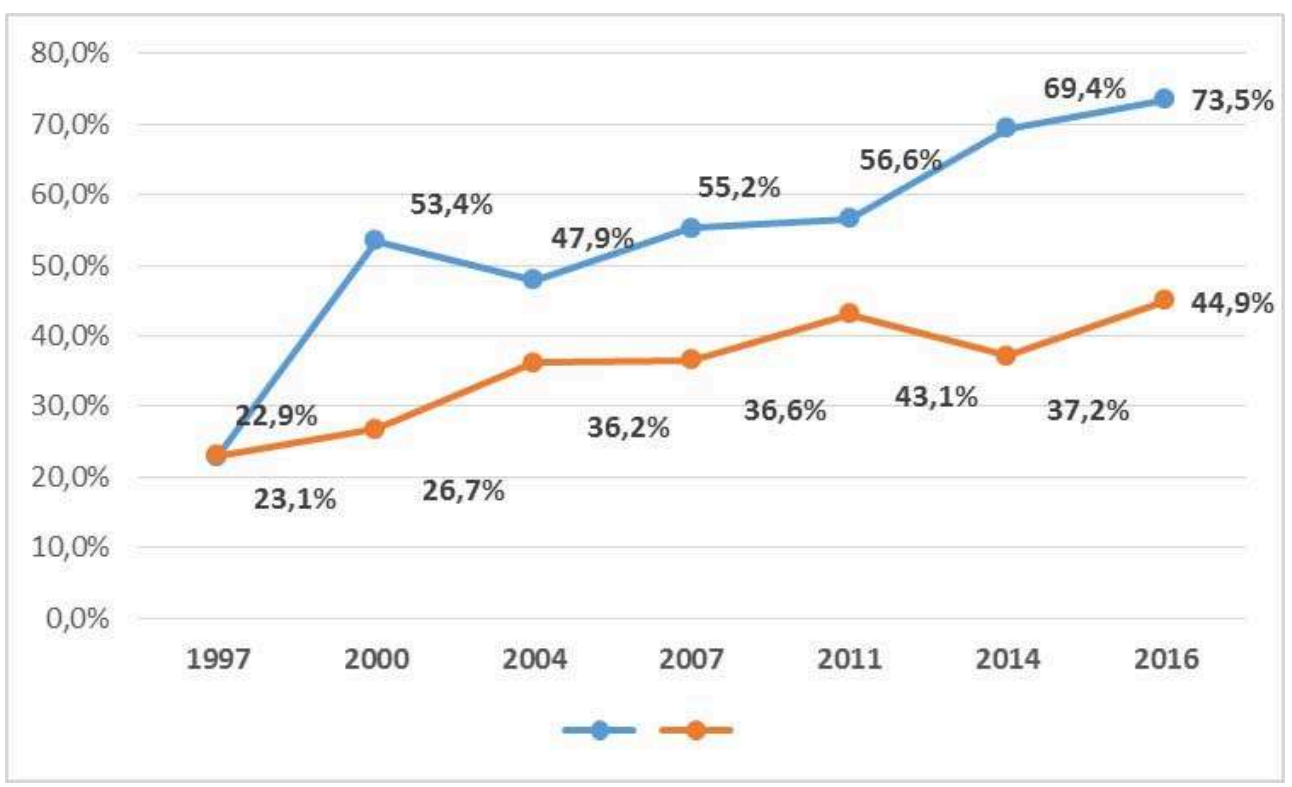

FIU Cuba Poll: 1997-2016 
On the diplomatic front, after a keen interest expressed in the 2000 poll for establishing diplomatic relations, presumably due to the tensions associated with the Elián González affair, the policy lost support but again became the preference of the majority in 2007. By 2016, a year after the establishment of relations on July 20, 2015, sixty-nine percent of Cuban Americans approved of the policy change. The expressed opposition to the embargo mirrors this trend. Opposition to the embargo was weak back in 1997 when only twenty-two percent of the Cuban American population opposed the long-standing policy. The latest poll reflected the changes in attitudes within the population as sixtythree percent opposed the continuation of the embargo (Figure 6).

Figure 6: Support for Diplomatic Relations and Opposition to Embargo

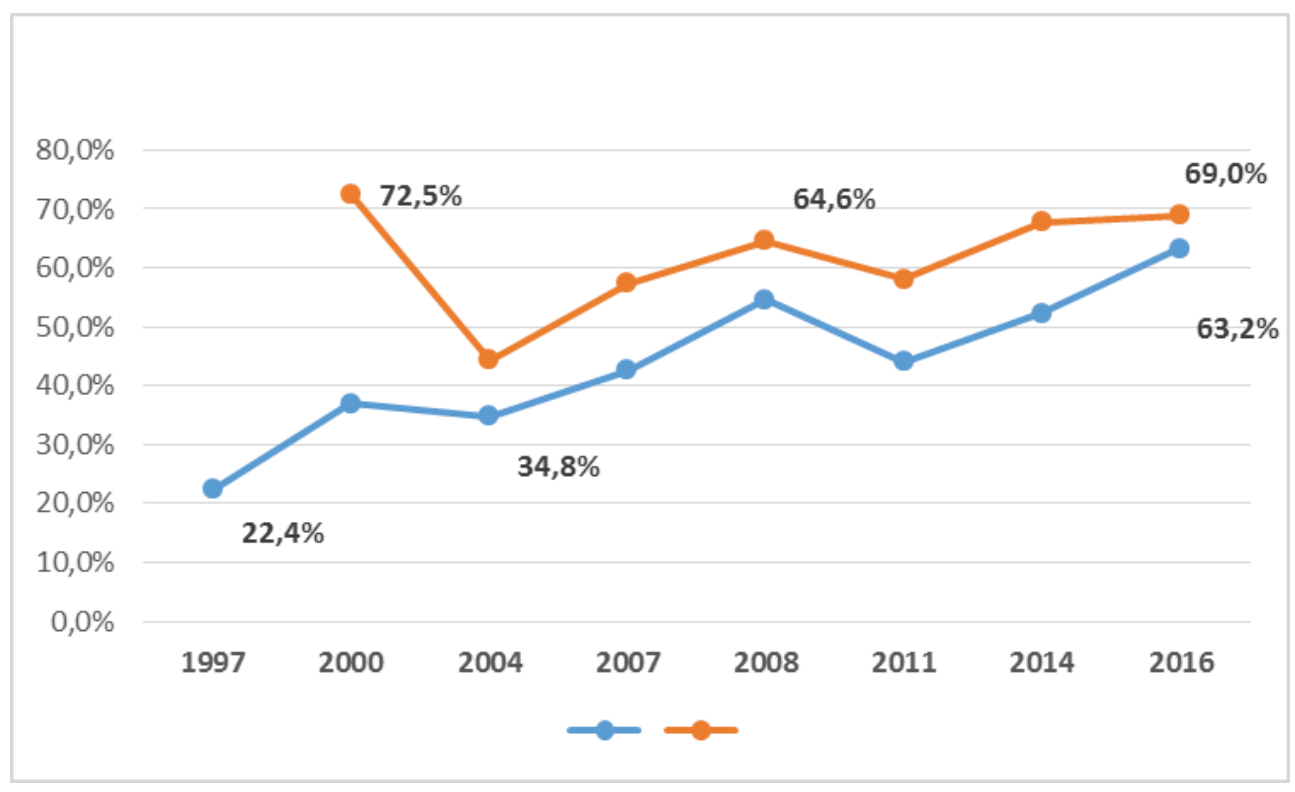

Source: FIU Cuba Poll: 1997-2016

21 The trend in the key variables presented is clear. The general population of Cuban Americans in Miami Dade County has undergone a transition from a population resisting engagement with Cuba to one interested in more engagement. Now let us review the data based on time of departure from Cuba and generation.

\section{Change by Waves and Generations}

Table 1 shows the percentage of Cuban Americans supporting the hardline isolationist policies, broken down for the four major waves and by generation (whether born in Cuba or not). The table shows a considerable gap between the weak support for engagement policies in the first post-revolutionary waves (1959-1979) and the highest level of support in the last wave (2005-2016). The attitudes of the Second Generation tend to align with the more engagement conscious attitudes of the last two waves. 
Table 1: Support for Isolationist Policies for Entire Combined Samples Percentage Supporting Isolationist Policies by Generation, Nativity, Event Waves, 2014

\begin{tabular}{|c|c|c|c|c|c|c|}
\hline $\begin{array}{l}\text { Independent } \\
\text { Variables }\end{array}$ & $\begin{array}{l}\text { Oppose } \\
\text { Embargo }\end{array}$ & $\begin{array}{l}\text { Favor } \\
\text { Diplomatic } \\
\text { Relations }\end{array}$ & $\begin{array}{l}\text { Favor } \\
\text { Unrestricted } \\
\text { Travel for } \\
\text { All }\end{array}$ & $\begin{array}{l}\text { Have } \\
\text { Traveled }\end{array}$ & $\begin{array}{l}\text { Support Food } \\
\text { sales }\end{array}$ & $\begin{array}{l}\text { Support Med } \\
\text { Sales }\end{array}$ \\
\hline \multicolumn{7}{|l|}{ Generations: } \\
\hline $\begin{array}{l}\text { Not Cuba } \\
\text { Born }\end{array}$ & $48.9 \%$ & $69.9 \%$ & $60.7 \%$ & $19.9 \%$ & $72.2 \%$ & $78.2 \%$ \\
\hline \multicolumn{7}{|l|}{ Waves: } \\
\hline 1959-1979 & $26.1 \%$ & $38.6 \%$ & $32.3 \%$ & $26 \%$ & $41.9 \%$ & $58.1 \%$ \\
\hline 1980-1994 & $43.3 \%$ & $57.9 \%$ & $53.2 \%$ & $41.6 \%$ & $62.7 \%$ & $70.8 \%$ \\
\hline $1995-2004$ & $58 \%$ & $73.8 \%$ & $77.5 \%$ & $49.4 \%$ & $80.3 \%$ & $87.3 \%$ \\
\hline $2005-2016$ & $70.5 \%$ & $89.5 \%$ & $87.4 \%$ & $35.1 \%$ & $89.9 \%$ & $91.3 \%$ \\
\hline
\end{tabular}

\section{FIU Cuba Poll, 1997-2016}

23 Figures 7 through 9 present the trends-clearly towards engagement-exhibited by the most recent waves of migrants. Support for sales of food and medicine trended strongly towards a support for more engagement among the most recently arrived cohorts of migrants. Those arriving during the first two decades after the Revolution are more supportive of selling medicine than food (58\% to $42 \%$ ) but the arrivals during the last two decades express a near consensus of support for selling both items to Cubans on the island. 
Figure 7: Support for Sales of Food and Medicine by Wave and Generation

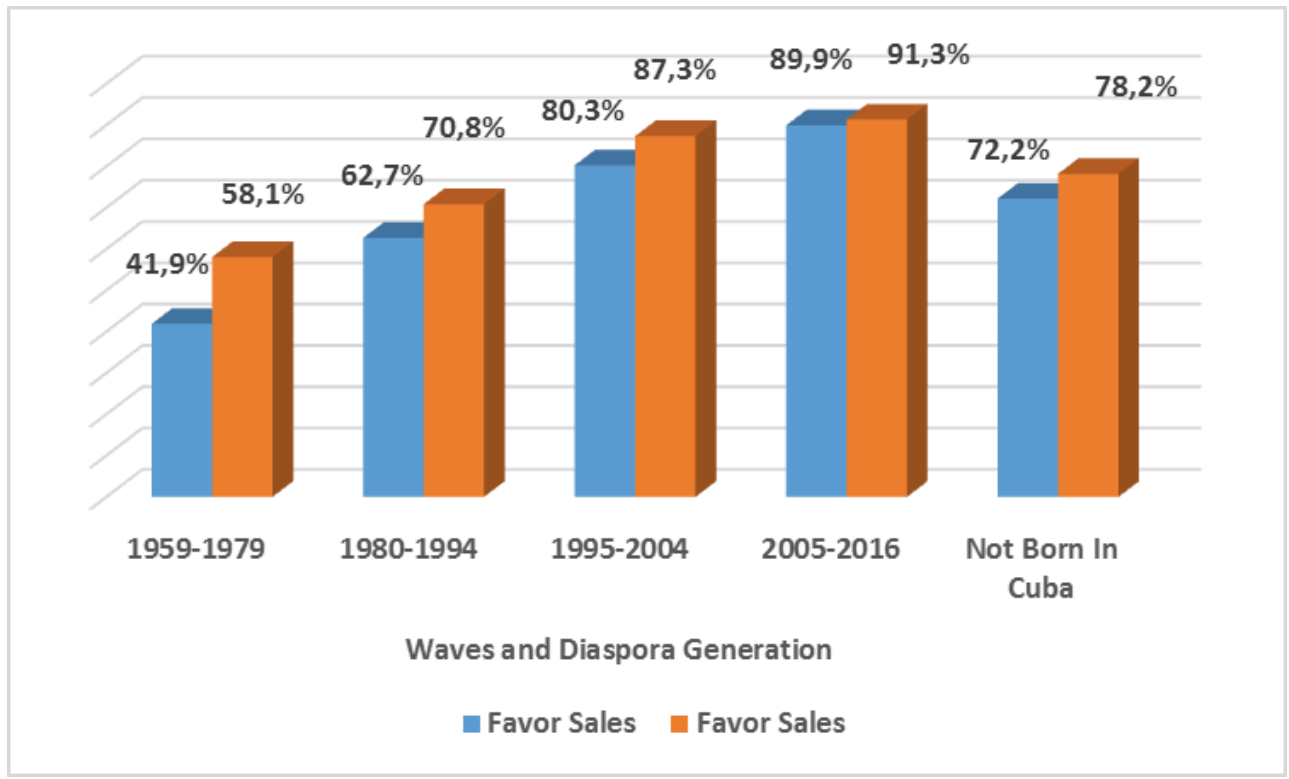

FIU Cuba Poll: 1997-2016

Figure 8: Support for Unrestricted Travel and Have Traveled to Cuba

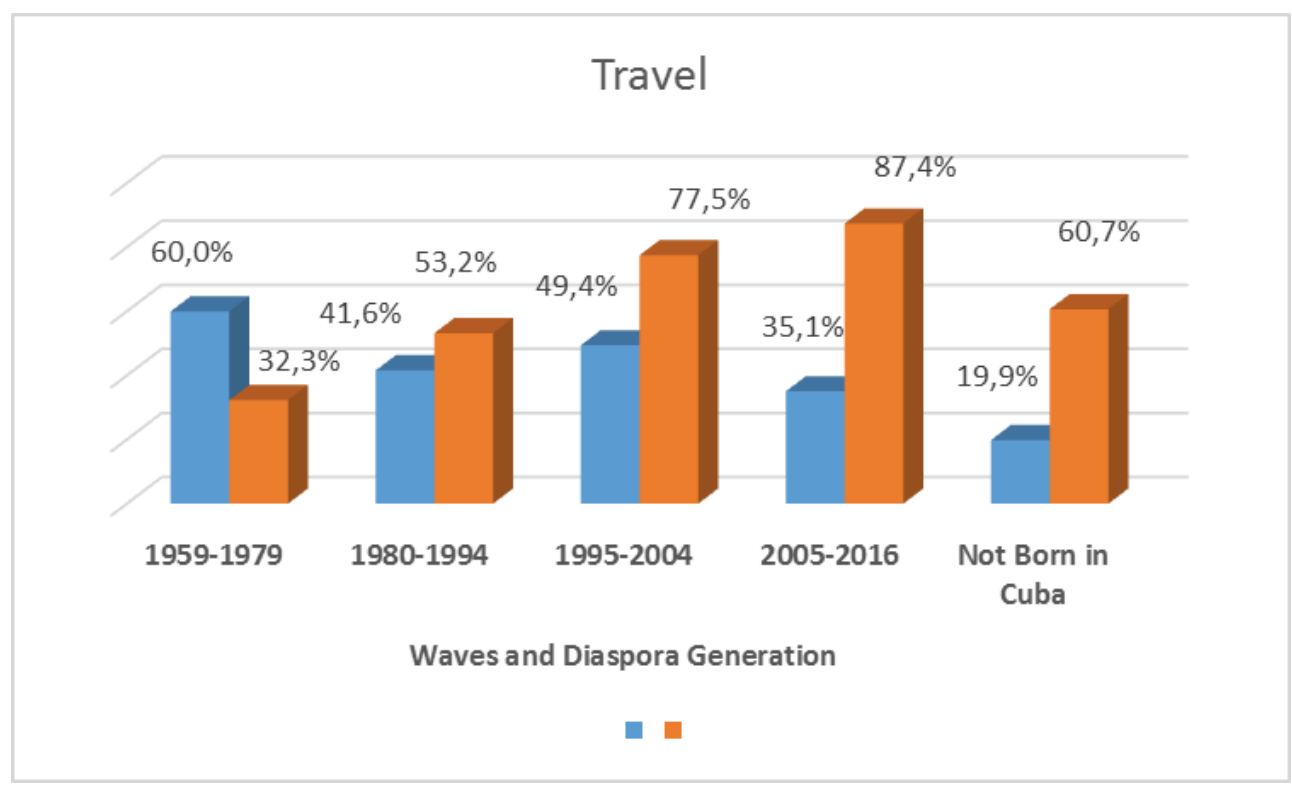

FIU Cuba Poll: 1997-2016 
Figure 9: Support for Diplomatic Relations and Embargo

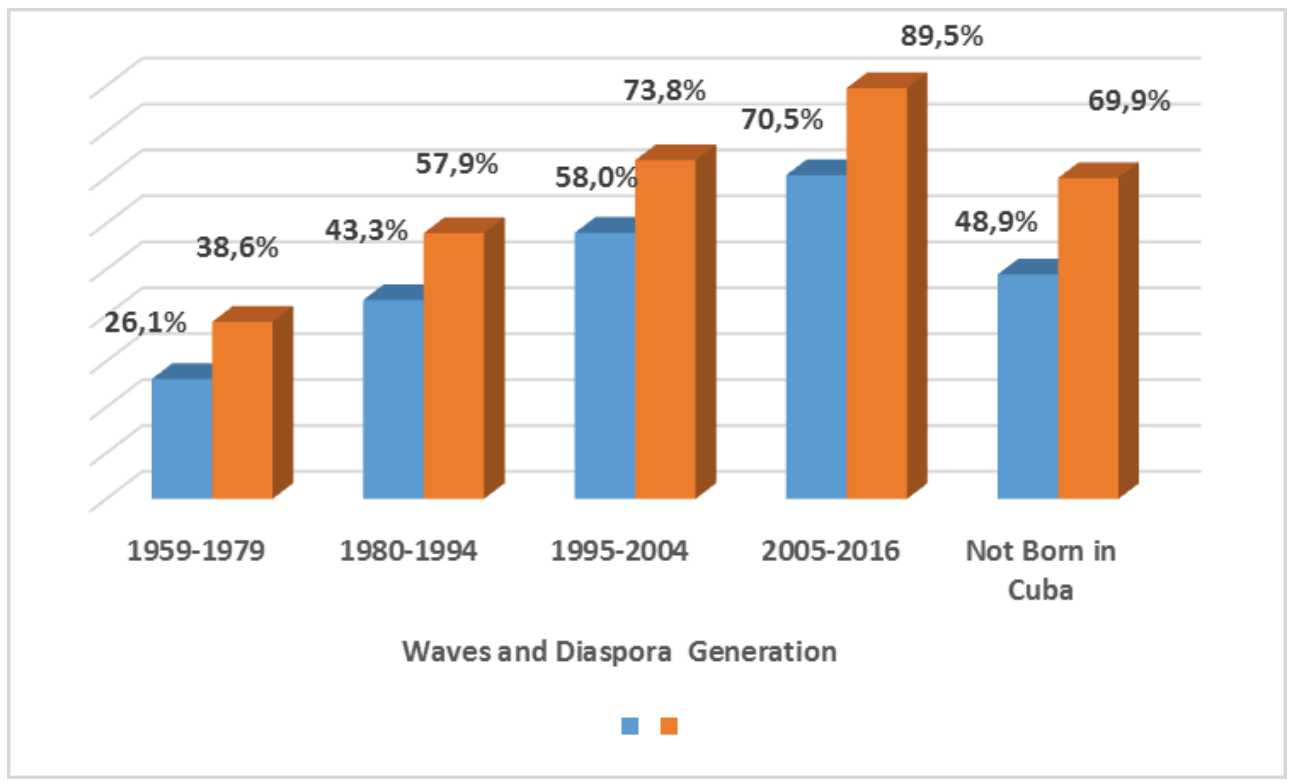

FIU Cuba Poll: 1997-2016

On the travel front, a minority of those leaving Revolutionary Cuba during the first two decades (32\%) support the opening of unrestricted travel to all Americans while a staggering eighty-seven percent of those leaving Cuba during the last decade support this change in policy. While a minority of Cubans have traveled to the island in all arrival cohorts, we can stipulate a difference in motivation, or lack thereof, between the earliest wave and the latter one to explain the low travel frequency. The earliest group have the resources and are not restricted from traveling to the island while the latter group is the poorest of the waves and, if they left illegally, might face restrictions to return. Predictably, fewer Second Generation Cuban Americans have traveled to the island but a sizable majority (61\%) support unrestricted travel by all Americans.

The establishment of diplomatic relations is supported by ninety-percent of the new arrivals but by less than thirty-nine percent of 1959-1979 migrants. Similarly, only twenty-six percent of 1959-1979 arrivals oppose the continuation of the embargo while over seventy-percent of those arriving during the last decade express opposition to the embargo.

In general, there is low support for the isolationist policies among Cubans not born in Cuba. This is evidence for the generational segmentation hypothesized in the literature. This is consistent with the expectation of less support for isolationist policies from those born and socialized outside the world transformed by the Cuban revolution. Even the embargo, which has strong majority support from the wave representing the parental generation, receives support of approximately fifty percent of the diaspora generation Cuban Americans. While the embargo as a symbolic form of political identity has a strong tradition in the Cuban American community, the symbolism of this policy (Girard C. et. al., 2010) is losing its impact on the U.S. born Cuban Americans. 


\section{Discussion} a group whose contemporary migration flow to the United States, and particularly to the South Florida region, is past the half century mark in its duration. That flow can be categorized into event driving migration waves, each with different push factors. These various cohorts have been progressively increasing the socioeconomic and ideological heterogeneity of the community. Also, a growing number of the members of the Cuban American community were not born in Cuba. If we refer to the Cuban immigrants to the Miami area as being composed of waves, the increasing number of U.S. born Cubans are the rising tide.

An identity as exiles has colored all aspects of the life of Cubans in the United States. It has resulted in an inordinate allocation of resources, including emotional energy, towards the primary task of reclaiming the homeland; it has shaped the social life of the Cuban American community and the focus of its voluntary associations; it has reinforced a sense of exceptionalism, setting them apart from other immigrant and Latino groups; it has made the relationship with the government of the homeland a perennially conflictive one; it has determined the nature of their participation in the political life of the new country. In short, the condition of exile has defined the purpose of the community and its reason for being here, and it is the condition that has largely shaped the image most Americans have of them.

If indeed exile has defined the condition of Cubans in the United States, then the biggest issue as we look toward the future is what will happen when they are no longer exiles. That is, what will this group look like when the entire context that has shaped their very identity changes dramatically? The research presented here, as well as the overall trends evident in other research utilizing the FIU Cuba Poll begins to answer this question.

When we are speaking of the Cuban American community in Miami, we are speaking of The research shows us the combination of ways that the post-exile identity of Cuban Americans is developing. One is through a generational transition as new generations, born in the United States, come of age. The other is through a fundamental change in the relationship with the homeland which is manifested through a demographic change in the diasporic community. The new arrivals have a different relation with the homeland and they continue to come to the Miami area. Over 500,000 Cubans have received Lawful Permanent Residence in the United States since 2000. (Figure 10) We estimate that over 60 percent of these new arrivals have settled in the south Florida area. These are not the displaced elites and others marked by the political confrontation of the early 1960s. These are mostly economic migrants who, although well educated, are leaving an economic condition that does not make use of their human resources. Their commitment to the "exile agenda" is more tenuous. 
Figure 10: Cubans Obtaining Lawful Permanente Residence (2000-2015)

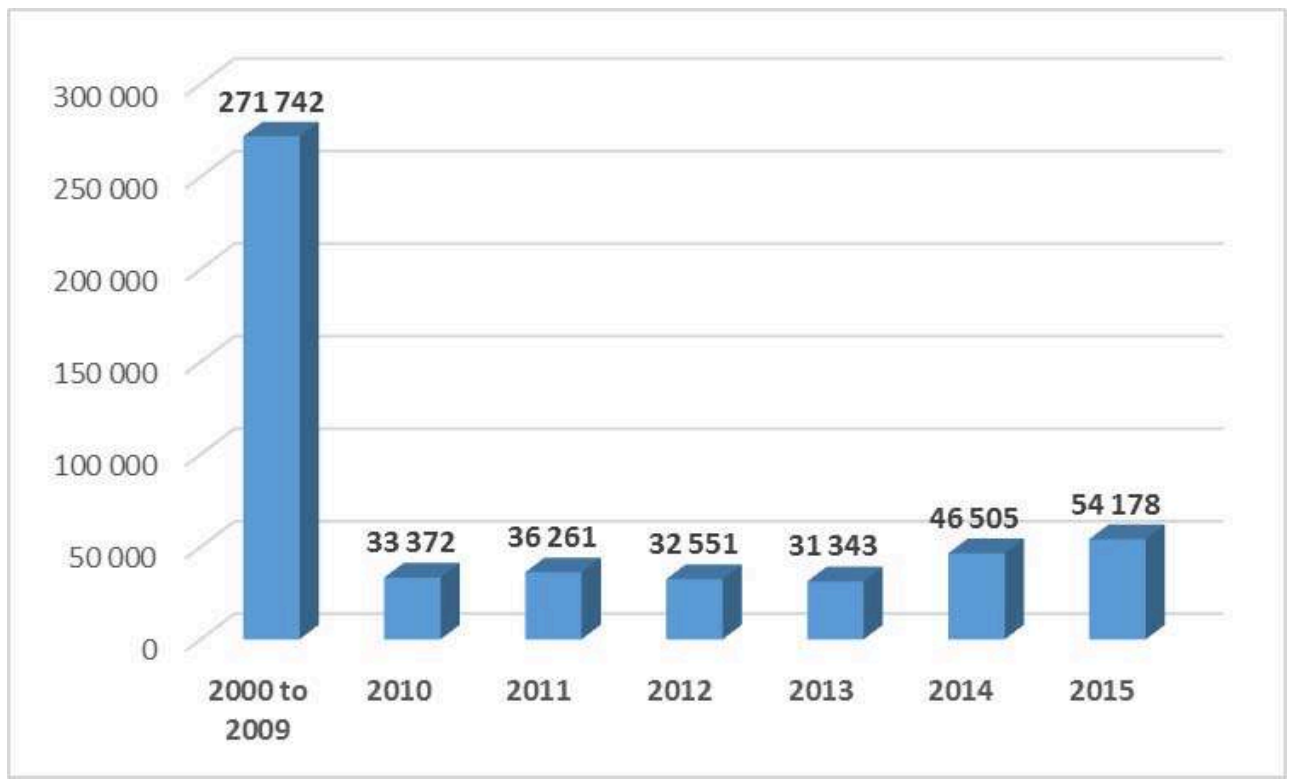

2015 Yearbook of Immigration Statistics, Table 2, Department of Homeland

Security.

31 Seventeen years into the 21st Century, the growth of the U.S.-born and the arrival of new waves have combined with mortality to whittle down the proportion of early exiles. Those arriving from 1960 to 1964 and during the Airlift barely accounted for a fourth of all Cubans in the United States in 2016.

Another way things are changing, and dramatically, is the transformation in the relationship with the homeland by the United States. The establishment of diplomatic relations and the trend towards increasing trade and travel, even with the embargo still in place, as well as the economic and immigration changes put in place by the Cuban government, have weakened the exile's ideological opposition to engagement. The death of Fidel Castro has "depersonalized" the conflict as well. The exile ideology has a strong oppositional nature. It cannot be sustained without its nemesis. For the new arrivals and the second generation, the identity of the "nemesis" is not clear.

In general terms, the attitudes of Cuban Americans towards the islands have been a result, in part, of the policies of the United States towards Cuba which, since the early 1960s until December 17, 2014, have been designed with the intent of isolating the Cuban nation and preventing U.S. citizens and institutions from establishing any kind of relations with individuals or organizations in Cuba. The ultimate goal of the isolationist policies at their inception was to promote regime change and undercut the sustainability of the Cuban Revolutionary government (LeoGrande W. and P. Kornbluh, 2015). For many decades it was assumed that the Cuban American community in the United States, particularly its members living in the Cuban enclave of South Florida, supported the isolationist purpose of the policies (Perez L., 1992). A more nuanced picture of Cuban American public opinion began to emerge in the 1990s as the FIU Cuba Poll established a reliable and continuing measure of Cuban American attitudes towards US/Cuba relations.

In this article I present data which quantify the changing attitudes of the Cuban American population in Miami-Dade County. Any synthesis of the ideological 
tendencies of the Cuban American community in Florida leads to the same conclusion: demographic changes are driving the ideological changes of the Cuban community in Miami. This is important because the trends could signal the end of the tendency to see the community as ideologically monolithic and uncompromising, and the emergence of the "new ideology of diaspora" directed at establishing and maintaining relationships with the island. If it is true that the ideology of the earlier emigres has exerted a major influence not only in the development of an immigrant community, but also on the foreign policy of the United States, the bearers of the more recent arrivals, the new ideology, will wield similar power.

Not only will the new arrivals influence decisions made in Washington about US/Cuba relations, but given their changing sociopolitical profile, new pan-ethnic alliances are made possible. The vast majority of Cubans in the United States are no longer exiles. The "exile ideology" (Grenier G. and Perez L., 2003) is weakening. The profile of the new Cubans is moving closer to that of other U.S. immigrant groups in terms of their political, social, and economic agenda. There will probably be a greater cultural and political integration with other Latino groups. There are already indications that the pan-ethnic labels so vehemently rejected by the first generation have made inroads among Cuban Americans born in this country. The Children of Immigrants Longitudinal Study found that among the Cuban-origin children in senior high school in Miami, thirty percent identified as "Hispanic" or "Latino" (Perez L., 2001: 107-108). An Hispanic or Latino identity is not derived from their parents. Virtually none of those children indicated that their Cuban-born parents identified as anything other than "Cuban." Similarly, exploratory research has shown, for example, that Cubans share with other Latinos in the State of Florida an interest in maintaining and expanding the health care coverage introduced in the Affordable Health Care Act (Aysa-Lastra M., et. al. 2014). This and other areas of cooperation with Latino populations throughout the State are made possible by the ongoing diversification of the Cuban American population.

The "new ideology of the diaspora" will also contribute to the normalization process recently initiated by the Obama/Castro administrations. The new arrivals are the growth sector of the Miami-Dade community and these are the Cuban Americans whose lives have been most significantly shaped by the Cuban reality; a reality governed not by the élan and suffering brought about by Revolutionary change but by the daily struggles of a poor Latin American country ninety miles away from the country with the strongest economy; its most influential neighbor for the last one hundred and fifty years. For better or worse.

\section{BIBLIOGRAPHY}

Aysa-Lastra, Maria, Guillermo J. Grenier and Hugh Gladwin, "Exile Identity and Attitudes toward Social Policies among Cuban Americans in Florida," in Jorge Duany (eds), Un Pueblo Disperso: 
Dimensiones sociales y culturales de la diáspora cubana., Valencia, Spain, Advena Vieja, 2014 p. 484-511.

Eckstein, Susan, The Immigrant Divide: How Cuban Americans Changed the U.S. and Their Homeland, New York, Routledge, 2009.

Eckstein, Susan and Lorena Barberia. "Grounding Immigrant Generations in History: Cuban Americans and Their Transnational Ties," International Migration Review, 36(3) 2002, p.799-837.

Fernandez, Gaston, "Race, gender and class in the persistence of the Mariel stigma twenty years after the Exodus from Cuba," International Migration Review 41(3), 2007, p.602-22.

Girard, Chris and Guillermo J. Grenier, "Insulating an Ideology: The Enclave Effect on South Florida's Cuban Americans," Latino Journal of Behavioral Sciences, 30 (4), 2008, p. 530-43.

Girard, Chris, Guillermo J. Grenier and Hugh Gladwin, "Exile Politics and Republican Party Affiliation: The Case of Cuban Americans in Miami," Social Science Quarterly, 93(1), 2012, p. 42-57.

Girard, Chris, Guillermo J. Grenier and Hugh Gladwin, "The Declining Symbolic Significance of the Embargo for South Florida's Cuban American," Latino Studies Journal, 8, 2010, p. 4-22.

Grenier, Guillermo J., "The More Things Change: The Creation, Maintenance and Persistence of the Cuban-Exile Ideology in Miami," Journal of American Ethnic History. Winter/Spring. 2006, p. 209-224.

Grenier, Guillermo J. and Hugh Gladwin, 2014 FIU Cuba Poll: How Cuban Americans in Miami View U.S. Policies Toward Cuba. Miami, Cuban Research Institute, 2014.

Grenier, Guillermo. J, and Lisandro Perez, The Legacy of Exile: Cubans in the United States. Boston, Allyn and Bacon, 2003.

Kunz, Egon F., "The Refugee in Flight: Kinetic Models and Forms of Displacement," International Migration Review, 7(2), 1973, p.125-146.

LeoGrande, William M. and Peter Korhnbluh, Back Channels to Cuba: The Hidden History of Negotiations between Washington and Havana. Chapel Hill, University of North Carolina Press, 2015.

Lopez, Mark H. and Jens Manuel Krogstad, “As Cuban Americans demographics change, so do views on Cuba", Fact Tank. Washington, D.C., Pew Research Center, December 23, 2014, http:// www.pewresearch.org/fact-tank/2014/12/23/as-cuban-american-demographics-change-so-doviews-of-cuba/, page consulted July 15, 2017.

Mannheim, Karl. "The Problem of Generations," in Essays on the Sociology of Knowledge, Paul Kecksckemeti, (ed.) New York, Oxford University Press, 1952, p. 276-322.

Newby, C. Allison and Julie Dowling, "Black and Hispanic: The Racial Identification of Afro-Cuban Immigrants in the Southwest," Sociological Perspectives 50(3), 2007, p. 343-66.

Pedraza-Bailey, Silvia, “Cuba's Exiles: Portrait of a Refugee Migration," International Migration Review, 19(1) 1985, p. 4-37.

Perez, Lisandro, “Cuban Miami”, in Guillermo J. Grenier and Alex Stepick III (eds.), Miami Now!: Immigration, Ethnicity, and Social Change, , Gainesville, University Press of Florida, 1992, p. 83-108.

Perez, Lisandro, "Growing Up in Cuban Miami: Immigration, the Enclave, and New Generations," in Rubén G. Rumbaut and Alejandro Portes (eds.), Ethnicities: Children of Immigrants in America, Berkeley and New York, University of California Press and Russell Sage Foundation, 2001, p. 91-125. 
Portes, Alejandro and Aaron Puhrmann, “A Bifurcated Enclave: The Economic Evolution of the Cuban and Cuban American Population of Metropolitan Miami," Cuban Studies Journal 43, 2015, p. 40-63.

Poyo, Gerald E., With All, and for the Good of All: The Emergence of Popular Nationalism in the Cuban Communities of the United States, 1848-1898. Durham, NC, Duke University Press, 1989.

Ritter, Archibald R.M., "Shifting Realities in Special Period Cuba," Latin American Research Review 45 (3), 2010, p. 229-238.

Sewell, William H., The Logics of History: Social Theory and Social Transformation. Chicago, University of Chicago Press, 2005.

United States Government Publishing Office (GPO), 1966, Public Law 89-732: 1161.

Uhlander, Carole J. and F. Chris Garcia, "Learning Which Party Fits: Experience, Ethnic Identity, and the Demographic Foundations of Latino Party Identification," in Gary M. Segura and Shaun Bowler, (eds.), Diversity in Democracy: Minority Representatives in the United States, Charlottesville, University of Virginia Press, 2005, p. 72-101.

\section{ABSTRACTS}

This article traces, for the first time, the changes in the opinions of Cuban Americans in South Florida on the topic of U.S./Cuba relations during the last twenty years using the FIU Cuba Poll as the data base. The analysis traces the changes in key variables from 1997 until the most recent poll concluded in August of 2016. These years marked the decades with the most intense migration of Cubans to the United States since the triumph of the Revolution. The analysis details how Cuban immigrants during this time relate to the island in material terms (remittances, investments, travel), and in ideological terms (attitudes towards maintaining the embargo, political ideology, etc.). Seven FIU Cuba Poll have been combined to present a broad vision of the changes in Cuban American political culture in South Florida. We find that it is not only the newcomers who want a rapprochement with their homeland, but the second and third generations of Cuban Americans also want more engagement.

El presente trabajo por primera vez traza los cambios de opiniones hacia Cuba por los Cubanos en el sur de la Florida durante los últimos veinte años; desde el 1997 hasta la más reciente encuesta, Agosto 2016. Estos años marcan las décadas con la más intensa migración de cubanos a los Estados Unidos desde el triunfo de la Revolución. La presentación detalla cómo estos inmigrantes se relacionan con la isla en términos materiales (remesas, inversiones, viajes), y también en términos ideológicos (actitudes hacia el mantenimiento del embargo, ideología política, etc.). Siete encuestas del FIU Cuba Poll se han combinado para presentar una visión amplia de los cambios en la cultura política del cubano-americano en el sur de la Florida. Encontramos que no solo son los recién llegados que desean un acercamiento con su patria, pero que muchos de los miembros de la segunda y tercera generación también desean un acercamiento con la isla.

Cet article retrace, pour la première fois, l'évolution des opinions des Cubains-Américains de Floride du Sud à propos des relations entre les Etats-Unis et Cuba durant les vingt dernières années, en utilisant les sondages de la Florida International University comme base de données, depuis 1997 jusqu'au sondage le plus récent conduit en août 2016. Ces années ont été marquées par la plus forte migration de Cubains vers les Etats-Unis depuis le triomphe de la révolution. Nous analysons le lien des immigrés cubains avec l'île en termes matériels (transferts d'argent/ remittances, investissements, voyages) et en termes idéologiques (attitude à l'égard de l'embargo, 
idéologie politique, etc.). Sept sondages FIU ont été compilés pour présenter un large panorama des changements dans la culture politique des Cubains-Américains en Floride du Sud. Notre analyse démontre que ce ne sont pas seulement les nouveaux venus qui souhaitent un rapprochement avec l'île mais également les deuxième et troisième générations de citoyens américains d'origine cubaine.

\section{INDEX}

Keywords: Cuban Americans, transition, ideological changes, demographic changes, migrations Palabras claves: Cubano Americanos, Transición, cambios ideológicos, cambios demográficos, migraciones

Mots-clés: Cubains-Américains, transition, changements idéologiques, changements démographiques, migration

\section{AUTHOR}

\section{GUILLERMO J. GRENIER}

Guillermo J. Grenier is Professor of Sociology and Chair in the Department of Global and Sociocultural Studies at Florida International University, the State university of Florida in Miami. Born in Havana, Cuba, Dr. Grenier is the author of numerous books and dozens of articles on labor, migration, immigrant incorporation, and Cuban American ideological profiles, particularly in the Greater Miami area and lectures nationally and internationally on his research. 